\title{
The Effects of Fashion Interest, Product Novelty and Product Quality on Brand Consciousness and Brand Loyalty in Fashion Apparel Purchase
}

\author{
Manilall Dhurup (Prof) \\ Executive Dean: Faculty of Management Sciences, Vaal University of Technology \\ Private Bag X021, Vanderbijlpark, 1900, Gauteng, South Africa \\ Email: royd@vut.ac.za
}

\section{Doi:10.5901/mjss.2014.v5n8p32}

\section{Abstract}

The study examines the relationship fashion interest, product novelty and product quality on brand consciousness and brand loyalty in apparel purchase in Gauteng, South Africa. The study is located within a post-positivist paradigm using a quantitative method. Participants were 199 randomly selected students registered in 2013 from a University in South Africa. Descriptive statistics were used to describe the composition of the sample. Structural equation modelling (SEM) was used to test the relationships between the constructs. Validity and reliability were assessed through confirmatory factor analysis (CFA) and Cronbach alpha values. The results show that that there are no significant casual relationships between fashion interest and brand consciousness. Significant casual relationships were found between product novelty and brand consciousness and product quality and brand consciousness. However, brand consciousness does not seem to influence brand loyalty. The study provides valuable implications for retailers and more specifically marketers, for the constant need to emphasise the product quality and product novelty aspects of fashion apparel in order generate opportunities for sales among this cohort of consumers.

Keywords: Fashion interest, product novelty, product quality, brand consciousness,brand loyalty.

\section{Introduction}

Interest in fashion transcends many domains and touches almost any kind of products such as apparel, automobiles, decoration, sport and music. The current study examines the apparel industry in particular as it accounted for approximately 1,252.8 billion spent dollars worldwide in 2006 (Le Bon \& Meruka, 2009). As a result of such spending, researchers and marketers alike have devoted considerable attention to understand the concept of fashion and explain why consumers adopt fashion products. Fashion is "a distinctive trend which is recognized, valued and adopted by a large number of individuals in a limited time-frame and in a defined space" (Le Bon \& Merunka, 2009:2). Fashion may be defined as a broadly based behavioural phenomenon evidenced in a variety of material and non-material contexts. Thus, clothing can help represent a personal identity. Fashion is conceptualized both as an object and behavioural process (Vieira, 2009). Consumers use fashion to differentiate themselves from others and manage their group affiliations (Gronow, 1997; Solomon \& Rabolt, 2004; Piamphongsant \& Mandhachitar, 2008). Thus clothing is primarily a means of communicating, not only one's personal identity, but also their social identity (Noesjirwan \& Crawford 1982). Shopping for clothes is one of the popular pastimes among people from all ages, different genders and cultural backgrounds. With the proliferation of design and image in the clothing sector, consumers need to take serious consideration during the buying processes.

\section{Consumer Fashion Interest}

Fashion involvement is defined as the perceived personal relevance or interest from the consumer regarding fashion clothing (Engel, Blackwell \& Miniard, 1995). Dress reflects cultural and material aspects of society and has importance in economic and social terms (Workman \& Lee, 2011) as it represents symbolic values endorsed by the group (Lurie, 1981; Noesjirwan \& Crawford, 1982; Auty \& Elliott, 1998; Meyers-Levy \& Sternthal, 1991; Hogg, Cox \& Keeling, 2000; Beaudoin, Moore \& Goldsmith, 2000; Michaelidou \& Dibb, 2006; Piamphongsant \& Mandhachitar, 2008). It is posited that if consumers have developed an interest in fashion, then they are more likely to be brand conscious. 


\section{Product Novelty}

Product novelty is described as a new or unique fashion products introduced into the market which gains the momentum and excitement from consumers who seek and try out the new fashion or fad (Schiffman \& Kanuk 2008). Sproles and Kendall (1986) identified product novelty as an important trait in consumer decision-making. It is posited that product novelty may lead to consumers becoming more brand conscious.

\section{Product Quality}

The perception of a high quality may be closely related to the differentiation and superiority of a particular brand and thus consumers may choose that brand over competing brands (McConnell, 1968). Consumers often develop perceptions about a brand based on quality (Doyle, 2001). Consumers may intend to purchase a brand or become brand conscious if they perceive that the brand offers the appropriate features, quality and performance (Ko, Kim \& Lee, 2009). A consumer will look at the quality and durability of products so that it can be used for a long time. The design is also an important motivation for purchasing fashion, especially with regard to garments as consumers assign more and more relevance to aesthetical appearance, like the line and look, value, style and quality of product (Hong, Pecotich \& Schultz, 2002; Wickliffe \& Psysarchik, 2001). It is therefore posited that product quality will lead to consumers becoming more brand conscious.

\section{Brand Consciousness}

Brands are at the very heart of marketing (Grant \& Stephen, 2006). A brand is a powerful tool to attract more consumers to buy particular products, especially clothing. Brand consciousness is an element of the decision-making process of consumers who are often oriented towards expensive and well known national and international brands of clothing (Fan \& Xiao 1998). Consumers who are interested in apparel brands tend to pay attention to the physical properties and features of the clothing that include quality and fit (Kaiser, 1997). According to Jamal and Goode (2001) a brand conscious consumer tends to place importance on attributes such as brand names. As far as the same level of product quality is concerned, consumers would prefer buying brand-name products (Bello \& Holbrook, 1995). With the influence of globalisation and media advertising, international brands have become popular in local markets which offer high potential of purchase (Delgado-Ballester \& Munuera-Aleman, 2005). Based on this affirmation, it is posited that students who are brand consciousness will have a positive perception towards brand loyalty.

\section{Brand Loyalty}

Brand loyalty is a consistent re-purchase of the brand which is accompanied by a favourable brand attitude (Sheth \& Mittal, 2004; Solomon, 2002). Lamb, Hair, McDaniel, Boshoff and Terblanche (2004) describe brand loyalty as a consistent preference for one brand over all others. Solomon (2002) points out that this preference is a conscious decision to continue buying the same brand.Consumers are likely to develop a favourite brand and accordingly, show brand loyalty in the case of high involvement products such as clothing. However, they are less likely to show a high brand loyalty on low involvement products (Sheth \& Mittal 2004:397).

\section{Purpose of the Study}

The primary purpose of the study was to examine the effects of fashion interest, product quality and product novelty on brand consciousness and brand loyalty. In addition, the study sought to establish the relationship between brand consciousness and brand loyalty.

Based on the literature review, the following conceptual framework and hypotheses was proposed. 


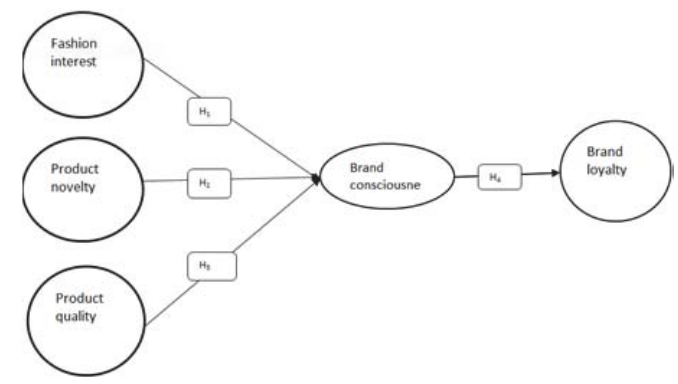

Figure 1: Proposed Conceptual Framework

\section{Proposed Hypotheses}

- $\quad \mathrm{H}_{1}$ : Fashion interest among university students positively and significantly influences brand consciousness.

- $\quad \mathrm{H}_{2}$ : Product novelty positively and significantly influences brand consciousness.

- $\quad \mathrm{H}_{3}$ : Product quality positively and significantly influences brand consciousness.

- $\mathrm{H}_{4}$ : Brand consciousness positively and significantly influences brand loyalty.

\section{Methodology}

A quantitative research paradigm was used in the study as the research sought to find relationships between variables through multivariate statistical techniques, namely confirmatory factor analysis and structural path modelling.

\subsection{The sample}

The sample comprised full-time university students. University students were chosen because of their indulgence in fashion and clothing. Participants in the study were 199 students randomly selected from undergraduate and post graduate programmes from a University in Southern Gauteng, South Africa. A list of students was generated from the Integrated Tertiary Software system (ITS) of the University. In addition, these students are the next generation of employees in the workplace who may add value towards an understanding of buying behaviour. Participation in the survey was voluntary and respondents were also assured that their responses would remain confidential and anonymous.

\subsection{Instrumentation}

A questionnaire was developed to tap the focal constructs of the study. First, items were pooled from the extant marketing and consumer behaviour literature. Items were adapted from the original 40-item Consumer styles Inventory (CSI) of Sproles and Kendall (1986) which focussed on the relevant constructs used in the study. The questionnaire comprised six sections. Section A solicited information on the demographic of the sample. Section B, C,D,E and $F$ comprised items on each of the constructs, namely, fashion interest, product quality, product novelty, brand consciousness and brand loyalty. Respondents were asked to indicate their degree of agreement or disagreement with each item based on five-point Likert scales with 1 denoting strongly disagree to 5 denoting strongly agree.

The questionnaire was then pilot tested $(n=40)$ on a student sample to examine its psychometric properties via reliability test (Cronbach alpha).

\section{Results and Discussion}

\subsection{Sample composition}

The sample comprised 35\% ( $n=70)$ males and $65 \%(n=129)$ females. Majority of the students, $50 \%(n=99)$ were under 22 years of age. Newspapers and magazines were the most popular reported media, $56 \%(n=111)$ from which students obtained information on where and what kind of clothing to buy. Boutiques that were located in malls were the most 
popular, $43 \%$ ( $n=86)$ were majority of the students shopped for clothing and accessories. Majority of the students, $62 \%$ $(n=124)$ shopped for clothing at least once a month.

\subsection{Test of the measurement model through confirmatory factor analysis (CFA)}

Structural equation modelling (SEM) with analysis of moment structures (AMOS) graphics version 21.0 was used to analyse the data and parameters are estimated using maximum likelihood method. The main data analysis is conducted following a two step approach suggested by Anderson and Gerbing (1998); firstly by validating the measurement model through goodness of fit measures and secondly fitting the data through a structural model. The former is accomplished primarily through confirmatory factor analysis, while the latter is accomplished through path analysis with latent variables ( Fornell \& Larcker,1981).

CFA was used to validate the measurement model that consisted of six constructs measured by 29 observed variables. Overall acceptable model fit are indicated by goodness-of-fit index (GFI) $\geqq 0.80$; adjusted goodness-of fit index (AGFI) $\geqq 0.800$; root mean square error of approximation (RMSEA) values $\leqq 0.08$; incremental index of fit (IFI), TuckerLewis index (TLI) and comparative fit index (CFI) values $\geqq 0.90$; and chi-square degrees of freedom ratio (CMIN/DF) value <3 (Fornell \& Larcker, 1981; Browne \& Cudeck, 1993). Recommended statistics for the final overall model assessment show acceptable fit of the measurement model to the data, $\mathrm{CMIN} / \mathrm{DF}=1.433 ; \mathrm{GFI}=0.86 ; \mathrm{IFI}=0.96 ; \mathrm{TLI}=$ 0.95; CFI = 0. 96; RMSEA = 0.046 (Schumacker \& Lomax, 2004).

\subsection{Reliability and validity}

Table 1 summarises the means, reliability and accuracy statistics through a confirmatory factors analysis approach. To assess reliability, Cronbach alpha coefficients were calculated for the five scales, namely, fashion interest, product novelty, product quality, brand consciousness and brand loyalty. All the scales showed good reliability, as follows: fashion interest $(\alpha=0.927)$, product novelty $(\alpha=0.824)$ product quality $(\alpha=0.829)$, brand consciousness $(\alpha=0.829)$ and brand loyalty ( $a=0.737$ ). Using AMOS 21.0, a confirmatory factor analysis was conducted. The factor loadings for the all four constructs ranged from 0.705 to 0.886 , showing that each of the scales was indeed based on one underlying factor. The construct validities of the latent constructs were evaluated by convergent and discriminate validity. The composite reliability (CR) of all the constructs were greater than the minimum criteria of 0.70 (Nunnally \& Bernstein, 1994), indicating adequate convergent validity. In addition to the above evidence of convergent validity, Fornell and Larcker (1981) suggests that the average variance extracted (AVE) provides evidence of the overall convergent validity of each construct. This measure indicates the amount of variance explained by the construct relative to the amount of variance that may be attributed to measurement error and should exceed 0.50 (Fornell \& Larcker,1981)). All AVE values exceeded 0.50 ranging from 0.84 to 0.96 . In terms of discriminant validity, Fornell and Larcker (1981) states that the AVE for each constructs should be greater than the squared correlations (i.e. shared variance) between that construct and any other construct. All the AVE values exceed the shared variance thus affirming discriminant validity.

Table 1: Reliability, means and accuracy analysis statistics

\begin{tabular}{|c|c|c|c|c|c|c|c|}
\hline Constructs & $\begin{array}{c}\text { Item } \\
\text { means }\end{array}$ & $\begin{array}{c}\text { Composite } \\
\text { means }\end{array}$ & Cronbach alpha & $\begin{array}{c}\text { Factor } \\
\text { loadings }\end{array}$ & $\begin{array}{c}\text { CR } \\
\text { values }\end{array}$ & Ave & $\begin{array}{c}\text { Shared } \\
\text { variance }\end{array}$ \\
\hline Fashion interest & - & 3.23 & 0.957 & - & 0.96 & 0.70 & 0.20 \\
\hline F10 & 3.40 & & & .871 & & & \\
\hline F9 & 3.16 & & & .838 & & & \\
\hline F8 & 3.10 & & & .875 & & & \\
\hline F7 & 3.01 & & & .841 & & & \\
\hline F6 & 3.23 & & & .770 & & & \\
\hline F5 & 3.11 & & & .886 & & & \\
\hline F4 & 3.33 & & & .852 & & & \\
\hline F3 & 3.17 & & & .820 & & & \\
\hline F2 & 2.96 & & & .851 & & & \\
\hline F1 & 3.22 & & & .831 & & & \\
\hline Product quality & - & 4.26 & 0.847 & - & 0.85 & 0.54 & 0.13 \\
\hline QC5 & 4.60 & & & .706 & & & \\
\hline
\end{tabular}




\begin{tabular}{|c|c|c|c|c|c|c|c|}
\hline QC4 & 4.39 & & & .789 & & & \\
\hline QC3 & 4.24 & & & .785 & & & \\
\hline QC2 & 4.20 & & & .863 & & & \\
\hline QC1 & 3.90 & & & .801 & & & 0.20 \\
\hline Product novelty & - & 3.58 & 0.880 & - & 0.91 & 0.72 & \\
\hline FC1 & 3.45 & & & .706 & & & \\
\hline FC2 & 3.16 & & & .789 & & & \\
\hline FC3 & 3.47 & & & .785 & & & \\
\hline FC4 & 3.83 & & & .863 & & & \\
\hline FC5 & 3.71 & & & .801 & & & \\
\hline Brand consciousness & - & 3.69 & 0.867 & - & 0.87 & 0.54 & 0.13 \\
\hline BC6 & 3.93 & & & .747 & & & \\
\hline BC5 & 3.71 & & & .705 & & & \\
\hline BC4 & 3.47 & & & .761 & & & \\
\hline BC3 & 3.58 & & & .738 & & & \\
\hline BC2 & 3.75 & & & .706 & & & \\
\hline BC1 & 3.60 & & & .747 & & & \\
\hline Brand loyalty & - & 3.59 & 0.835 & - & 0.84 & 0.63 & 0.04 \\
\hline BL3 & 3.65 & & & .774 & & & \\
\hline BL2 & 3.26 & & & .790 & & & \\
\hline BL1 & 3.13 & & & & & & \\
\hline
\end{tabular}

C.R= Composite reliability; Ave= Average variance reliability; Factor loadings computed through a confirmatory factor analysis (CFA) approach using AMOS (21.0). Cronbach a values were computed using SPSS (version 21.0).

\subsection{Structural model and hypotheses testing}

A structural model was constructed to examine the hypothesised relationship among the constructs. The goodness of fit statistics, indicate the overall acceptability of the structural model analysed, are acceptable: CMIN/DF=1.249; GFI=0.901; $\mathrm{IFI}=0.984 ; \mathrm{TLI}=0.981 ; \mathrm{CFI}=0.983 ; \mathrm{RMSEA}=0.035$. These results are reported in Table 2.

Table 2: Results of the Structural Equation Model Analysis

\begin{tabular}{l|c|c|c|c}
\hline \multicolumn{1}{c|}{ Proposed hypotheses } & Hypothesis & Path coefficients & p-value & Rejected/supported \\
\hline Fashion interest $\rightarrow$ Brand consciousness & $\mathrm{H} 1$ & 0.106 & 0.053 & Rejected \\
\hline Product novelty $\rightarrow$ Brand consciousness & $\mathrm{H} 2$ & 0.247 & $0.003^{*}$ & Supported \\
\hline Product quality $\rightarrow$ Brand consciousness & $\mathrm{H} 3$ & 0.345 & $0.000^{\star \star}$ & Supported \\
\hline Brand consciousness $\rightarrow$ Brand loyalty & $\mathrm{H} 4$ & 0.225 & 0.057 & Rejected \\
\hline
\end{tabular}

* Significant at $p<0.05$ ** significant at $p<0.01$. CMIN/DF=0.1247. GFI=0.901, IFI=0.984, TLI=0.981, CFI=0.983, MSEA $=0.035$

The hypothesis, $\mathrm{H}_{1}$, the coefficient estimates for the paths from fashion interest to brand consciousness is not significant $(y=0.106, p>0.05)$. The hypothesis is not supported (rejected). The path analysis indicate that an interest in fashion does not necessary result in students becoming brand conscious. Although brand consciousness has shown to play an important part in the consumer purchase process and in decision-making (Sproles \& Kendall, 1986; Gutman \& Mills, 1982) there seem to be no causal relationship with fashion orientation and brand consciousness. Though students may have a strong fashion sense, which is largely derived from the mass media, which they consider it prior to shopping (Kim, 1998), it does not make them brand conscious.

A directional influence from product novelty to brand consciousness is found, supporting $\mathrm{H}_{2}(\mathrm{\gamma} 0.247, \mathrm{p}<0.05)$. These consumers are likely to gain excitement and pleasure from seeking out new things. They have motivation to keep up-to-date with styles and fashion trends. They also show variety seeking behaviour (Sproles \& Kendall, 1986; Bakewell \& Mitchell, 2003). Product novelty is the curiosity of students to seek variety and difference in clothing (Wang et.al., 2005) and they try to express themselves by being the first to try the style and their desire to keep up with the current fashion trends (Phau \& Teah, 2009). Hence, they tend to become more brand conscious, seeking out both national and international clothing brands.

Likewise, the influence between product quality to brand consciousness is also found, supporting $\mathrm{H}_{3}(\mathrm{y}=0.2345$, $p<0.01$ ). Previous research results show that quality is an important factor when purchasing apparel products (Kim \& 
Shim, 2002). Quality of clothing is considered as an important element in buying decisions. The consumer will look at quality and durability of the clothing that can be used for a long time. Furthermore, Yoo, Donthu and Lee (2000) posit that brand consciousness will be increased with the help of promoting positive perceived product quality.

The $\mathrm{H}_{4}$ is not supported, indicating no significant relationship between brand consciousness and brand loyalty $(\mathrm{Y}$ $=0.225, p>0.05$ ). The results show that that being merely conscious of a brand not necessarily leads to brand loyalty. Previous research has demonstrated that positive brand association rather than brand consciousness leads towards brand loyalty (Atilgan, Aksoy \& Akinci, 2005).

\section{Limitations and Implications for Further Research}

Although the study adds to the growing literature on the possible relationships amongst the constructs used in the study, there are some limitations in this regard. The small sample size of this study can be seen as a limitation of this research. The results of this research are therefore not generalizable to other contexts as the sample was based on students only. In future it can be interesting to replicate the study with a bigger sample size and other consumers as different populations may exhibit different shopping styles and preferences. The sample was restricted to apparel purchase only. The study could be extended to other types of consumer products. Although the study focused on apparel in general, it did not specify the different types of apparel and whether they were national or international brands. In future, a distinction should be made between national and international apparel brands that are available in the market. Majority of the students in the sample were black students. Whilst this is in keeping with the demographics of the university student population, it is worthy to extend the study at other universities that have diversity in terms of different race and cultural groups.

\section{Conclusion}

As the study is a snapshot of the possible relationships among the constructs within a university setting, it could be used as a conceptual background for future studies relating to these constructs within the apparel market. The results of the hypotheses indicate that only fashion interest and product novelty influence brand consciousness.

\section{References}

Anderson, J.C., \& Gerbing, D.W. (1988). Structural equation modelling in practice: a review and recommended two-step approach. Psychological Bulletin, 103(3):411-423.

Atilgan, E., Aksoy, S., \& Akinci, S. (2005). Determinants of brand equity: a verification approach in the beverage industry in Turkey. Marketing Intelligence \& Planning, 23(30): 237-248.

Auty, S., \& Elliot, R. (1998). Fashion involvement, self-monitoring and the meaning of brands. Journal of Product \& Brand Management, 7(2):109-123.

Azizi, S., \& Makkizadeh, C. (2012).Consumer decision-making style: the case of Iranian young consumers. Journal of Management, 4(2):88-111.

Beaudoin, P., Moore, M.A., \& Goldsmith, R.E. (2000). Fashion leaders' and followers' attitudes toward buying domestic and imported apparel. Clothing and Textiles Research Journal, 18(1):56-64.

Bello, D. C., \& Holbrook, M.B. (1995) Does an absence of brand equity generalize across product classes? Journal of Business Research, 34(2):125-131.

Blakewell, C., \& Mitchell, V. (2003). Generation Y consumer-decision making styles. International Journal of Retail \& Distribution Management, 31(2):95-106.

Browne, M.W., \& Cudeck, R. (1993). Alternative ways of assessing model fit. In K.A Bollen, J.S. Long (Eds.), Testing Structural Equation Models, (pp. 136-161). Newbury Park, CA: Sage.

Delgado-Ballester, E., \& Munuera-Aleman, J.L. (2005). Does brand trust matter to brand equity? Journal of Product \& Brand Management, 14(3):187-196.

Doyle, K.O. (2001). Ethnicity and Money. American Behavioural Scientist, 45(2), 177-351.

Engel, J.F., Blackwell, R.D., \& Miniard, P.W. (1995). Consumer Behaviour. (8th ed.). New York: Dryden Press.

Fan, J.X., \& Xiao, J.J. (1998). Consumer decision-making styles of young Chinese adults. Journal of Consumer Affairs, 32(20):275-294.

Fornell, C., \& Larcker, D.F. (1981). Evaluating structural equations models with unobserved variables and measurement error. Journal of Marketing Research, 18(1):39-50.

Grant, I.J., \& Stephen, G.R. (2006). Communicating culture: an examination of the buying behaviour of "tweenage" girls and key societal communicating factors influencing the buying process of fashion clothing. Journal of Targeting, Measurement and Analysis for Marketing, 14(2): 101-114.

Gronow, J. (1997). The Sociology of Taste. London: Routledge. 
Gutman, J., \& Mills, M.K. (1982). Fashion life style, self-concept, shopping orientation, and store patronage: An integrative analysis. Journal of Retailing, 2:64-86.

Hogg, M.K., Cox, A.J., \& Keeling, K. (2000). The impact of self-monitoring on image congruence and product/brand evaluation. European Journal of Marketing, 34(5/6): 641-66.

Hogg, M.K., Cox, A.J., \& Keeling, K. (2000). The impact of self-monitoring on image congruence and product/brand evaluation. European Journal of Marketing, 34(5/6):641-666.

Hong, F.C., Pecotich, A., \& Schultz, C. (2002). Brand name translation: language constraints,

product attributes, and consumer perceptions in East and Southeast Asia. Journal of International Marketing, 10: $29-45$

Jamal A., \& Goode, M.M.H. (2001). Consumers and brands: a study of the impact of self- image congruence on brand preference and satisfaction. Marketing Intelligence \& Planning, 19(7): 482-492.

Kaiser, S.B. (1997). The social psychology of clothing. (2nd ed.). New York (NY): Fairchild Publications.

Kim, M.S. (1988). Segmentation of the Korean apparel market $s$ determined by the life style differences of Korean college women. Unpublished doctoral dissertation, Ohio State University, Columbus.

Kim, Y.M., \& Shim, K.Y. (2002). The influence of internet shopping mall characteristics and user traits on purchase intent. Irish Marketing Review, 15(2), 25-34.

Ko, E., Kim., E.Y., Lee, E.K. (2009). Modelling consumer adoption of mibile shopping for fashion products in Korea. Psychology \& Marketing, 26:669-687.

Lamb, C.W., Hair, J.R., McDaniel, C., Boshoff, C., \& Terblanche, N.S. (2004). Marketing (1st ed.). Cape Town: Oxford University Press.

Le Bon., C. \& Merunka., D. (2008). Consumer-based fashion equity: A new concept to understand and explain fashion products adoption. Australia and New Zealand Academy Conference (ANZMAC). Shifting the focus from mainstream to offbeat, (1-3 December 2008), Olympic Park, Sydney, Australia.

Lurie, A. (1981). The language of clothes. London: Henry Holt and Company.

McConnell, J. D. (1968). Effects of pricing on perceptions of product quality. Journal of Marketing Research, 5:300-303.

Meyers-Levy, J., Sternthal, B. (1991). Gender differences in the use of message cues and judgements. Journal of Marketing Research, 28:84-96.

Michaelidou, N., \& Dibb, S. (2006). Product involvement: an application in clothing. Journal of Consumer Behaviour, 5(5): $442-453$.

Noesjirwan, J. A., \& Crawford, J. M. (1982). Variations in perception of clothing as a function of dress form and viewers' social community. Perceptual \& Motor Skills,54: 155-163.

Nunnally, J.C., \& Bernstein, I.H. (1994). Psychometric theory. New York: NY: Mc Graw-Hill.

O'Cass, A. (2002). An assessment of consumer's product, purchase decision, advertising and consumption involvement in fashion clothing. Journal of Economic Psychology, 21:545-576.

Phau, I., \& Teah, M. (2009). Devil wears (counterfeit) Prada: a study of antecedents and outcomes of attitudes towards counterfeits of luxury brands. Journal of Consumer Marketing, 26(1):15-27.

Piamphongsant, T., \& Mandhachitar, R. (2008). Psychological antecedents of career women's fashion clothing conformity. Journal of Fashion Marketing \& Management, 12(4):438-455.

Schiffman, L.G., \& Kanuk, L.L. (2008). Consumer Behaviour. (10 th ed.). New Jersey: Prentice-Hall.

Schumacker, R.E., \& Lomax, R.G. (2004). A beginner's guide to structural equation modelling. Mahwah, NJ: Psychology Press.

Sheth, J.N., \& Mittal, B. (2004). Customer behaviour: A managerial perspective. (2nd ed.). Ohio: South-Western.

Solomon, M.R. (2002). Consumer Behaviour: A European perspective. London: Prentice-Hall.

Solomon, M.R., \& Rabolt, N.J. (2004). Consumer Behaviour in fashion. Upper Saddle River, New Jersey: Prentice-Hall.

Sproles, G.B., \& Kendall, E.L. (1986). A methodology of profiling consumers' decision-making styles. Journal of Consumer Affairs, 20(2): 267-279.

Sproles, G.B., \& Kendall, E.L. (1986). A methodology for profiling consumer decision-making styles. Journal of Consumer Affairs, 20:267-279.

Vieira, A.A. (2009). An extended theoretical model of fashion clothing involvement. Journal of Fashion Marketing \& Management, 13(2):179-200.

Wickliffe, V., \& Pysarchik, D. (2001). A Look at Product Attributes and Enhancers of Group Integration Among U.S. and Korean Consumers. International Journal of Retail and Distribution Management, 29(2):99-108.

Workman, J.E., \& Lee, S.H. (2011). Materialism, fashion consciousness and gender: a cross-cultural study. Journal of Consumer Studies, 35(1): 50-57.

Yoo, B., Donthu, N., \& Lee, S. (2000). An examination of selected marketing mix elements and brand equity. Journal of the Academy of Marketing Science, 28(2):195-211. 